\title{
Ontogeny of Hepatic Type I Insulin-Like Growth Factor Receptors in the Rat
}

\author{
PHILIP A. GRUPPUSO, TARIK D. WALKER, AND PATRICIA A. CARTER \\ Section of Biochemistry, Brown University, and Department of Pediatrics, Rhode Island Hospital, \\ Providence, Rhode Island 02903
}

\begin{abstract}
We studied the pre- and postnatal developmental regulation of the hepatic type I IGF receptor in the rat. Fetal rat liver membranes bound IGF-I throughout the latter part of gestation (d 17 to 21). After birth, binding diminished rapidly, reaching barely detectable levels by the 13th postnatal d. However, the presence of type I IGF receptors was readily demonstrated by affinity-labeling throughout the immediate postnatal period and in adult rats. Furthermore, IGF-I-dependent autophosphorylation of type $I$ receptors could be seen in both fetal and adult liver membranes. Fasting for $\mathbf{4 8 ~} \mathrm{h}$ in adult rats led to a 2to 3-fold increase in affinity-labeled type I IGF receptors. In contrast, nutrient deprivation to the fetus, via maternal fasting, did not alter fetal hepatic IGF-I binding or affinitylabeling of the type $I$ receptor. These results support a role for the IGF and the type I IGF receptor in the autocrine/ paracrine regulation of hepatic growth through the latter stages of gestation in the rat. The demonstration of enzymatically active type I IGF receptors in adult liver, and their increased expression in fasted adult rats is consistent with an autocrine/paracrine role for hepatic IGF-I in the adult. (Pediatr Res 29: 226-230, 1991)
\end{abstract}

\section{Abbreviations}

TGF, transforming growth factor

EGF, epidermal growth factor

IGFBP, IGF binding protein

The effects of the mitogenic hormones IGF-I and IGF-II can be mediated via binding to the type I IGF receptor (1). This transmembrane glycoprotein is a heterotetramer with considerable primary structure similarity to the insulin receptor (2). Like the insulin receptor, the type I IGF receptor $\alpha$-subunit contains an extracellular, cysteine-rich ligand-binding domain, whereas the $\beta$-subunit intracellular domain is a tyrosine-specific protein kinase capable of autophosphorylation (3-5). This enzyme activity presumably is involved in signal transmission via phosphorylation of proteins exogenous to the receptor. However, no functionally defined exogenous substrates for this receptor have been defined as of yet. Although both IGF-I and IGF-II can also bind to the type II IGF receptor (1), it has not been demonstrated definitively that this $M_{r}=274000$ monomer, which is identical to the cation-independent mannose-6-phosphate receptor (6), is involved in IGF signal transmission.

The growth and differentiation of the fetal liver near term is a complex process, regulation of which probably involves multiple

Received March 27, 1990; accepted October 31, 1990

Correspondence: Philip A. Gruppuso, M.D., Division of Pediatric Endocrinology and Metabolism, Rhode Island Hospital, 593 Eddy Street, Providence, RI 02903.

Supported by National Institutes of Health Grant HD 24455. polypeptide growth factors. Specific mRNA for IGF-I and IGFII are present in fetal rat liver, with IGF-II predominating (7). Similarly, the mRNA for TGF- $\alpha$, a homologue of EGF that acts through the EGF receptor (8), is present in fetal rat liver (9) However, the potential importance of TGF- $\alpha$ as a fetal hepatic growth factor in the rat is diminished by the finding that expression of the EGF receptor occurs late in gestation on d 20 (10). Another polypeptide growth factor, TGF- $\beta$, is probably synthesized in fetal liver $(9,11)$. It is, however, an inhibitor of DNA synthesis in rat fetal hepatocytes in primary cultures (Gruppuso $P$, unpublished observation). Just as we had done for the TGF, we decided to study the ontogeny of the type I IGF receptor to assess the potential role for the IGF in fetal hepatic growth and differentiation in the rat. Given the importance of nutritional factors in the regulation of IGF secretion (12), we also studied the effects of impaired intrauterine growth on hepatic type I IGF receptor expression. Finally, changes during the perinatal period were also examined, as was receptor expression in normal and fasted adult rats.

\section{MATERIALS AND METHODS}

Pregnant Sprague-Dawley rats (Charles River Breeding Laboratory, Wilmington, MA) were delivered by cesarean section on d 17 through 21 of gestation. Control dams ( 15 litters) were fed standard laboratory food ad libitum. For the experimental group (four litters), mothers were fasted for $48 \mathrm{~h}$ before delivery on $\mathrm{d}$ 21 while being given free access to water. Cesarean section was performed under pentobarbital anesthesia $(50 \mathrm{mg} / \mathrm{kg}$, intraperitoneally). With the placenta adherent to the uterus, the fetuses were exsanguinated via an axillary incision. Their livers were removed, flash frozen in liquid nitrogen, and stored at $-70^{\circ} \mathrm{C}$ until use. In addition, several rats were allowed to deliver spontaneously. Their pups were killed by decapitation under pentobarbital anesthesia 1, 2, 5, and $13 \mathrm{~d}$ after birth. Finally, adult male rats (125-150 g) were killed with or without prior fasting (ad libitum water intake) for $48 \mathrm{~h}$. As in previous studies from our own laboratory $(13,14)$, maternal fasting for $48 \mathrm{~h}$ led to fetal growth retardation with an $\sim 10 \%$ decrease in mean fetal carcass weight and an $\sim 25 \%$ decrease in mean fetal liver weight.

Membrane preparations were made as previously described (14) from the pooled livers from each litter or individual postnatal livers. Yields of membrane protein per unit wet weight were similar for all groups. Membranes were diluted to a protein content of $10 \mathrm{mg} / \mathrm{mL}$ and stored at $-70^{\circ} \mathrm{C}$ until use.

Human IGF-I was obtained from Bachem, Inc. (Torrance, CA). 3-[125 I]iodotyrosyl-IGF-I with a sp act of approximately $2000 \mathrm{Ci} / \mathrm{mmol}$ was obtained from Amersham Corp. (Arlington Heights, IL). Particulate membrane binding assays were done as described previously (10). Briefly, labeled ligand, unlabeled ligand, and $50 \mu \mathrm{g}$ membrane protein were incubated in a total volume of $150 \mu \mathrm{L}$ for $2 \mathrm{~h}$ at $15^{\circ} \mathrm{C}$. Bound ligand was separated from unbound ligand by centrifugation at $12000 \times g$ for 10 min. Results were expressed using Scatchard analysis (15) to 
permit determination of $k_{d}$ and maximum hormone binding per unit membrane protein. Determination of $k_{d}$ was based on the slope of a tangent drawn at $50 \%$ of maximal binding.

Affinity-labeling of hepatic membranes was accomplished by incubation of labeled ligand $(0.15 \mu \mathrm{Ci} ; 300 \mathrm{pM}$, final concentration) and $240 \mu \mathrm{g}$ membrane protein with or without unlabeled ligand in a total volume of $240 \mu \mathrm{L}$ for $2 \mathrm{~h}$ at $15^{\circ} \mathrm{C}$ (buffers as for binding assays). Cross-linking was performed by the addition of $0.25 \mathrm{mM}$ disuccinimidyl suberate followed by incubation on ice for $15 \mathrm{~min}$. Membranes were collected by centrifugation (as for binding assays), suspended in gel electrophoresis sample buffer with reducing agent, and placed in a boiling water bath for 5 min. Samples ( $50 \mu$ g protein per lane) were analyzed by PAGE (6.5\%, except where noted) in the presence of dodecyl sulfate. Molecular weights were determined using the following standards: myosin, $\mathrm{M}_{\mathrm{r}}=200000 ; \beta$-galactosidase, 116250 ; phosphorylase $b, 97400$; BSA, 66200 ; ovalbumin, 42700 . Gels were exposed to Kodak XAR-5 film in the presence of intensifying screens at $-70^{\circ} \mathrm{C}$. Radiolabeled bands were quantified with a Hoefer model no. 300S scanning densitometer (Hoefer Scientific Instruments, San Francisco, CA) connected to a Hewlett-Packard model no. 3390A integrator (Hewlett-Packard Co., Palo Alto, CA).

To assess the contribution of membrane-associated IGFBP to membrane binding, we utilized analysis by Western ligand blot as described previously (16). Briefly, membrane protein $(100 \mu \mathrm{g})$ was subjected to PAGE ( $12 \%$ gel) under nonreducing conditions. Separated proteins were transferred electrophoretically to a nitrocellulose membrane. Binding proteins were detected by overnight incubation with ${ }^{125}$ I-IGF-II $\left(10^{6} \mathrm{cpm}\right)$ followed by autoradiography.

For studies on type I IGF receptor autophosphorylation, receptors were purified by wheat germ lectin affinity chromatography. Rat liver membranes were extracted with $1 \%$ Triton $X-100$. The extract ( $10 \mathrm{mg}$ protein for fetal samples, $25 \mathrm{mg}$ for adult samples) was applied to a 2-mL column of wheat germ lectin-Sepharose (Pharmacia Fine Chemicals, Piscataway, NJ) and unbound proteins were applied a second time. The column was washed with $50 \mathrm{~mL}$ of $40 \mathrm{mM}$ imidazole- $\mathrm{HCl}, 0.5 \mathrm{M} \mathrm{NaCl}, 10 \%$ glycerol, $0.05 \%$ Triton X-100, pH 7.2. Receptors were then eluted with the same buffer containing $0.3 \mathrm{M} \mathrm{N}$-acetyl glucosamine. Fractions that bound ${ }^{125}$ I-insulin (17) were pooled. In previous stud-

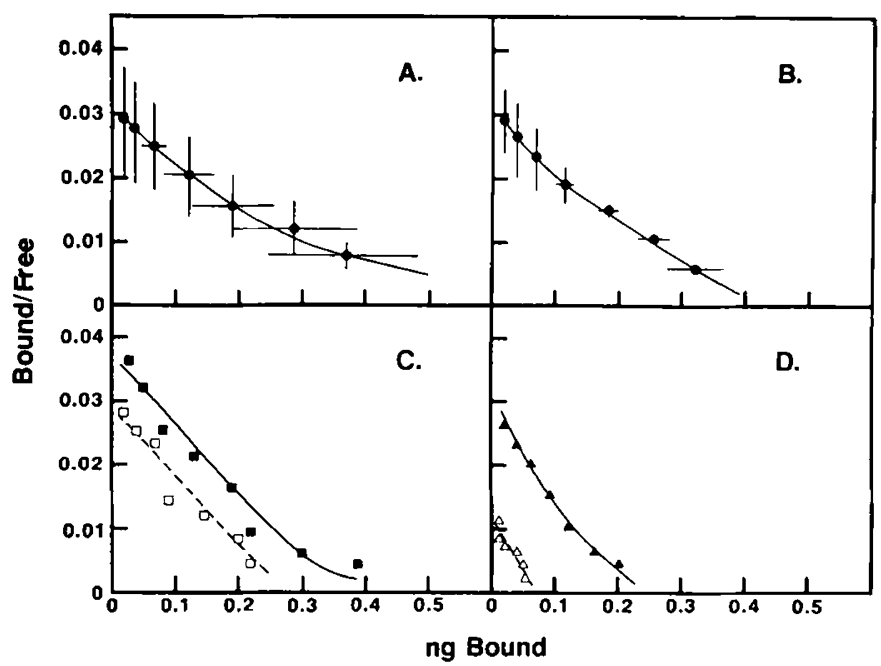

Fig. 1. Binding of IGF-I to liver membranes from pre- and postnatal rats. Data are plotted as Scatchard analyses. The four panels represent the following groups: $A$, term (21 d) fetuses of control mothers $(n=6)$; $B$, term fetuses of fasted mothers $(n=4) ; C$, representative analyses from two 1-d-old rats; and $D$, representative analyses from 2-d-old (closed triangles) and 5-d-old (open triangles) rats. Error bars represent SEM. For estimates of maximum binding capacity, $0.3 \mathrm{ng}$ bound corresponds to $0.78 \mathrm{pmol} / \mathrm{mg}$ membrane protein.

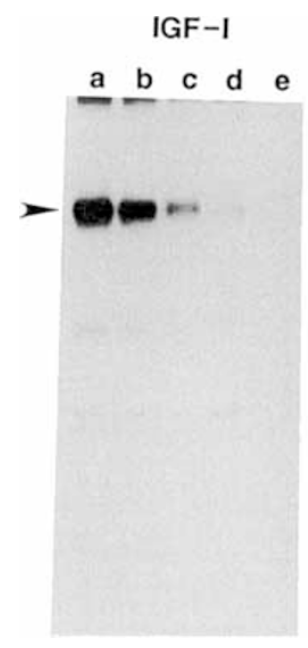

Insulin

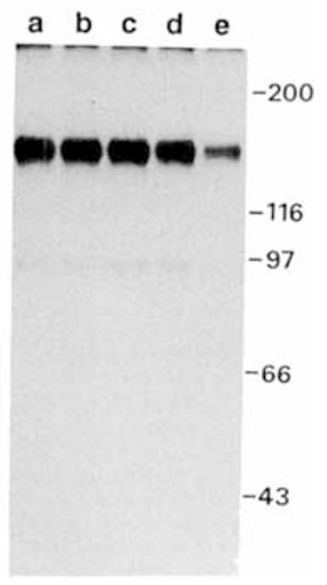

Fig. 2. Displacement of ${ }^{125}$ I-IGF-I from $21-d$ fetal liver membranes by IGF-I and insulin. Membranes were affinity labeled in the presence of varying concentrations of unlabeled hormone ( $a$, none; $b, 1 \mathrm{nM} ; c, 10$ $\mathrm{nM} ; d, 100 \mathrm{nM}$; and $e, 1000 \mathrm{nM})$ and proteins separated on a $7.5 \%$ polyacrylamide gel. The autoradiogram was developed after exposure to the dried gel for $2 \mathrm{~d}$. The arrow denotes the position of the $\mathrm{M}_{\mathrm{r}}=135000$ type I IGF receptor $\alpha$-subunit. Numbers to the right of the figure denote molecular weights of the marker proteins in $\mathrm{kD}$.
A.

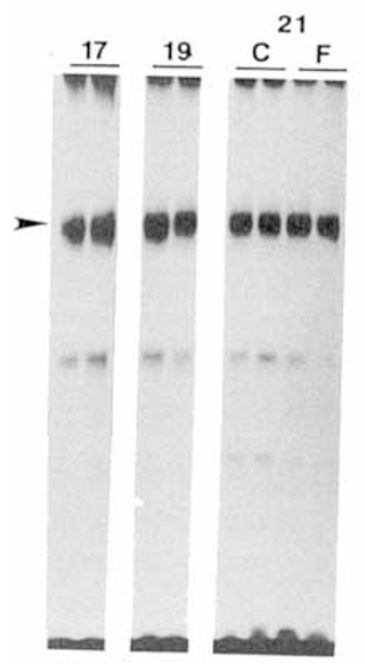

B.

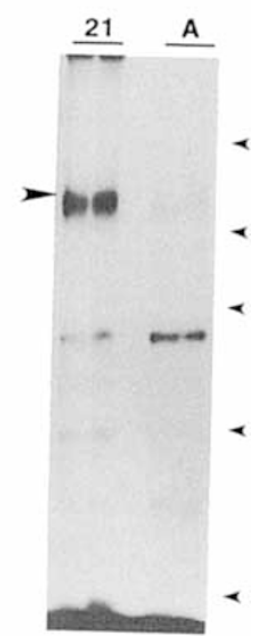

Fig. 3. Affinity-labeling of rat liver membranes with ${ }^{125}$ I-IGF-I. Incubations were carried out in the absence of unlabeled ligand. Panel $A$ shows analyses of two fetal liver membrane preparations from each of the following groups: 17, 19, and $21 \mathrm{~d}$ gestation, and 21-d fetuses of fasted mothers. The experiment shown in panel $B$ compares two 21-d fetuses with two normal adult males. The arrow to the left denotes the position of the $M_{r}=135000$ type I IGF receptor $\alpha$-subunit. Exposure time for the autoradiogram was $2 \mathrm{~d}$. Small arrows to the right show the positions of molecular weight markers corresponding to those in Figure 2.

ies, we have found that this pool also contains EGF receptors (10) as well as type I IGF receptors (see below).

Receptor autophosphorylation was accomplished by incubating receptor preparations $(50 \mu \mathrm{L})$ with hormones $(20 \mu \mathrm{L})$ for 30 $\min$ at $30^{\circ} \mathrm{C}$. Hormone activation was followed by the addition of $15 \mu \mathrm{L}$ containing $10 \mu \mathrm{Ci}\left[\gamma^{-32} \mathrm{P}\right] \mathrm{ATP}$ and $\mathrm{MnCl}_{2}$ to achieve final concentrations of $8.8 \mu \mathrm{M}$ and $4.4 \mathrm{mM}$, respectively. After incubation at $4^{\circ} \mathrm{C}$ for $5 \mathrm{~min}$, receptor phosphorylation was terminated by adding $15 \mu \mathrm{L}$ of 2 -mercaptoethanol ( $15 \mathrm{mM}$, final concentration) and EDTA (6 mM final concentration). Samples were processed for gel electrophoresis as described above. 


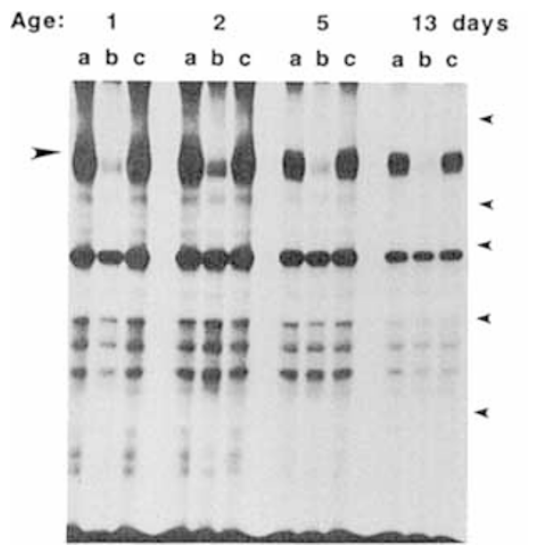

Fig. 4. Affinity-labeling of postnatal rat liver membranes with ${ }^{125} \mathrm{I}$ IGF-I. Samples from one animal at each age were affinity labeled in the presence of $(a)$ no unlabeled ligand, $(b) 45 \mathrm{nM}$ IGF-I, and (c) $55 \mathrm{nM}$ insulin. The arrow to the left denotes the position of the $M_{r}=135000$ type I IGF receptor $\alpha$-subunit. Exposure time for the autoradiogram was $7 \mathrm{~d}$. Small arrows to the right show the positions of molecular weight markers corresponding to those in Figure 2.

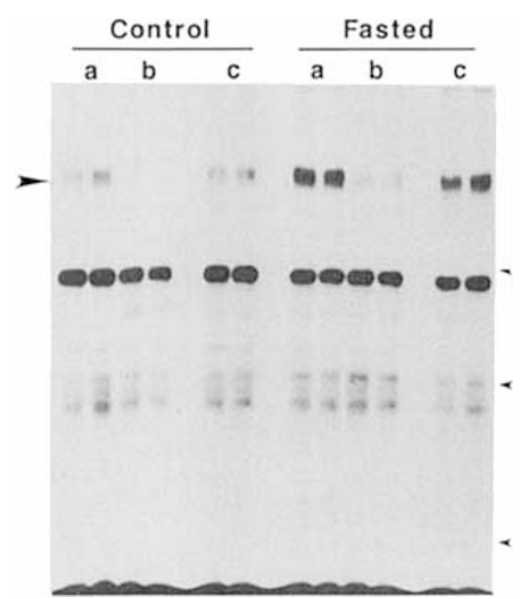

Fig. 5. Affinity-labeling of normal and fasted adult rat liver membranes with ${ }^{125}$ I-IGF-I. Samples from two animals at each age were affinity-labeled in the presence of $(a)$ no unlabeled ligand, $(b) 45 \mathrm{nM}$ IGF-I, and (c) $55 \mathrm{nM}$ insulin. The arrow to the left denotes the position of the $\mathrm{M}_{\mathrm{r}}=135000$ type I IGF receptor $\alpha$-subunit. Exposure time for the autoradiogram was $7 \mathrm{~d}$. Small arrows to the right show the positions of molecular weight markers corresponding to those in Figure 2.

\section{RESULTS}

The binding of ${ }^{125} \mathrm{I}-\mathrm{IGF}$-I to fetal and adult rat liver membranes was not displaced by the addition of insulin at concentrations below $0.2 \mu \mathrm{M}$ (not shown). However, ${ }^{125} \mathrm{I}-\mathrm{IGF}-\mathrm{I}$ was displaced by $>80 \%$ at $1.3 \mu \mathrm{M}$ insulin, indicating that the major binding species in our membrane preparations was the type I IGF receptor. Binding to fetal liver membranes from control $21-\mathrm{d}$ fetuses (Fig. 1A) was similar to that obtained using membranes from growth-retarded fetuses of fasted mothers (Fig. $1 B$ ). Binding to membranes from 17- and 19-d fetuses (not shown) was qualitatively similar. All fetal groups displayed nearly linear Scatchard plots with a $\mathrm{k}_{\mathrm{d}}$ of approximately $2 \mathrm{nM}$. A near doubling in mean maximal binding occurred from d $17[0.53 \pm 0.29 \mathrm{pmol} / \mathrm{mg}$ membrane protein (mean $\pm \mathrm{SD}), n=3$ ] to $\mathrm{d} 21(1.00 \pm 0.26, n$ $=6 ; p<0.05$ by unpaired $t$ test).

Liver membrane IGF-I binding capacity decreased after birth (Fig. $1 C$ and $D$ ). By the 5 th postnatal d, binding capacity was decreased by 80 to $90 \%$ without a significant change in affinity. At and beyond d 13 of age, affinity and receptor number could not be estimated because of inadequate specific binding.
As was the case for the binding studies, affinity labeling of rat liver membranes with ${ }^{125}$ I-IGF-I was sensitive to inhibition by unlabeled IGF-I (Fig. 2) with insulin having no effect at concentrations below $1 \mu \mathrm{M}$. This result is consistent with affinitylabeling of the $\mathrm{M}_{\mathrm{r}}=135000$ type I IGF receptor $\alpha$-subunit with insignificant labeling of the insulin receptor $\alpha$-subunit of the same molecular mass.

Affinity-labeling of type I IGF receptor $\alpha$-subunit in fetal membranes (Fig. $3 A$ ) increased little with advancing gestation, in contrast to estimates of receptor number based on Scatchard analysis. Intensity of the affinity-labeled type I receptor on d 17 of gestation was $84 \pm 30 \%$ of levels on d 21 (mean of four independent experiments). Affinity-labeling was not altered in term growth-retarded fetuses of fasted mothers.

A comparison of adult and term fetal liver membranes (Fig. $3 B$ ) revealed an $\sim 90 \%$ diminution in affinity-labeling (adult = $11 \pm 6 \%$ of term fetal levels; mean of six experiments). Affinitylabeling of membranes from 1-, 2-, 5-, and 13-d-old rat pups (Fig. 4) showed a gradual decrease of $50 \%$ from d 1 to 13. Competition with unlabeled IGF-I and insulin confirmed that this represented a decline in labeling of the type I IGF receptor $\alpha$-subunit.

To compare the effects of postnatal fasting with those of intrauterine nutrient deprivation (maternal fasting), fed and fasted ( $48 \mathrm{~h}$ ) adult rats were studied (Fig. 5). Fasting led to a 2to 3-fold increase in affinity labeling of the type I IGF receptor $\alpha$-subunit, based on densitometric analysis.

Our data showed a discrepancy between the degree with which binding and affinity-labeling increased before term. To determine if this difference between methods could be attributed to the presence of IGFBP, we analyzed membrane preparations by ligand blot analysis (not shown). A ligand blot of duplicate membrane samples from 17-, 19-, and 21-d fetuses revealed abundant binding with $\mathrm{M}_{\mathrm{r}}=31000$. The intensity of the affinitylabeled band increased by 30 to $50 \%$ between 17 and $21 \mathrm{~d}$ gestation. An IGFBP with $M_{r} \sim 37000$ was also detected at much lower and relatively constant levels in the same samples. The significance of these results are addressed below.

Because signal transmission via the type I IGF receptor probably involves activity of the intrinsic receptor tyrosine kinase, we evaluated this receptor activity. Rather than using an exogenous, nonphysiologic substrate, receptor kinase activity was measured as IGF-I-dependent receptor autophosphorylation. Half-maximal receptor phosphorylation occurred between 15 and $30 \mathrm{nM}$ IGF-I (Fig. 6), indicating specificity of IGF-I for activation of the type I IGF receptor kinase. Type I IGF receptor $\beta$-subunit from $17-, 19-$, and $21-\mathrm{d}$ fetal and adult (control and fasted) livers were capable of autophosphorylation at the lowest concentration of IGF-I that elicited maximal phosphorylation (32 nM; Fig. 7). The degree of receptor autophosphorylation was roughly proportional to receptor content. (Note that 2.5 times more membrane protein was used for receptor purification from adult liver.)

\section{DISCUSSION}

Using ligand binding analysis, affinity-labeling, and receptor autophosphorylation studies, we have shown that the type I IGF receptor is present and enzymatically active in fetal rat liver from d 17 of gestation until term. Quantification by competitive binding indicated that receptor levels nearly doubled between $d$ 17 and 21 . The expression of the type I IGF receptor in fetal liver during the latter part of gestation is consistent with a role for the IGF in promoting fetal hepatic growth and differentiation. The postnatal decrease in receptor expression seen with both methods is consistent with the developmental regulation of the type I IGF receptor gene (18), which declines to approximately $70 \%$ of term fetal levels by 1 wk of age. Conversely, IGF-I mRNA expression (18) shows a marked increase in hepatic levels by 2 wk of age. Thus, the postnatal disappearance of the type I IGF receptor may result from decreased gene expression, in- 

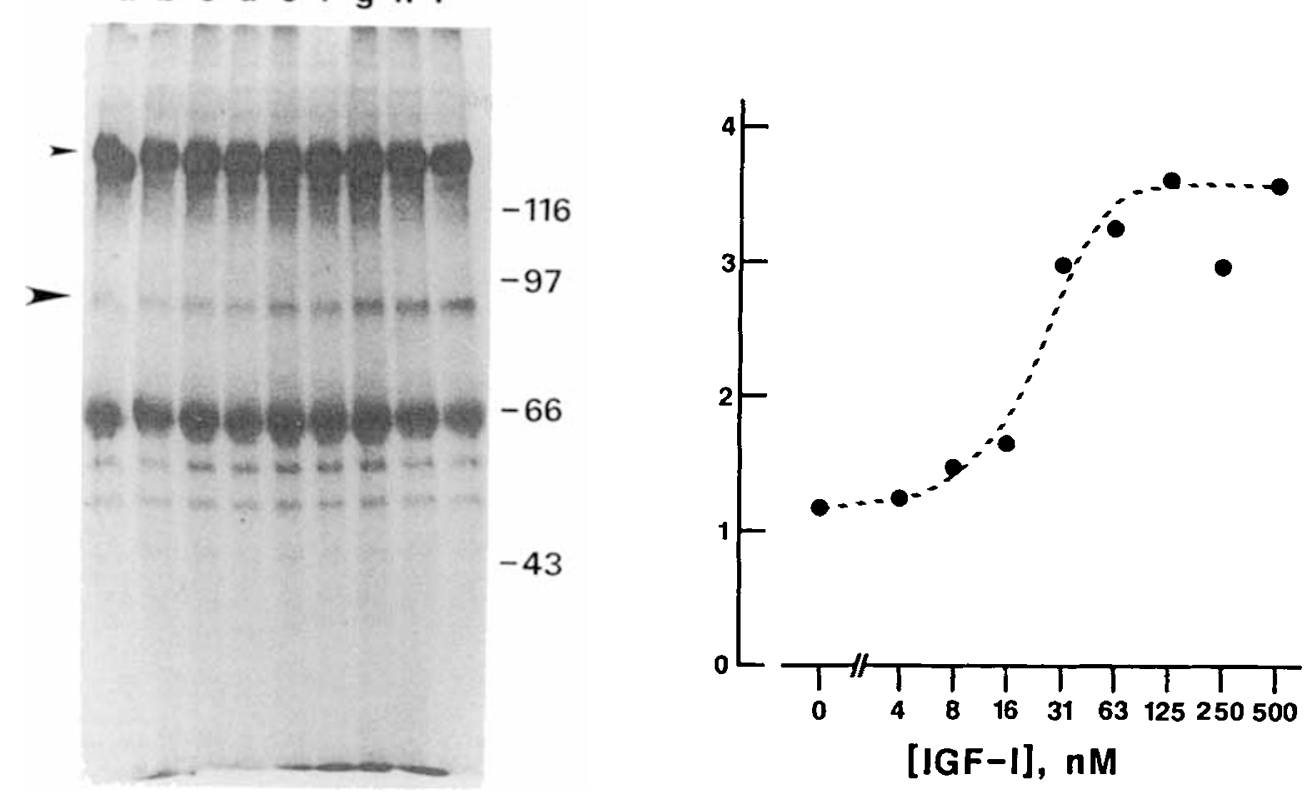

Fig. 6. Dose-dependent autophosphorylation of the type I IGF receptor. Liver membranes from a term (21-d) fetus were used as a source for wheat germ lectin purification of receptors. Autophosphorylation was carried out in the presence of varying concentrations of IGF-I. Lanes $a$ through $i$ correspond to the points shown in the graph, which depicts the density of the $M_{\mathrm{r}}=95000$ type I IGF receptor $\beta$-subunit (denoted by the large arrow next to the autoradiogram). The smaller arrow shows the position of the $\mathrm{M}_{\mathrm{r}}=170000 \mathrm{EGF}$ receptor. The graph shows the intensity of the $\mathrm{M}_{\mathrm{r}}=95000$ type I IGF receptor $\beta$-subunit based on densitometric analysis of the autoradiogram, which was developed after exposure to the dried gel for $3 \mathrm{~d}$. Numbers to the right of the autoradiogram correspond to the position and molecular weight in $\mathrm{kD}$ of marker proteins.

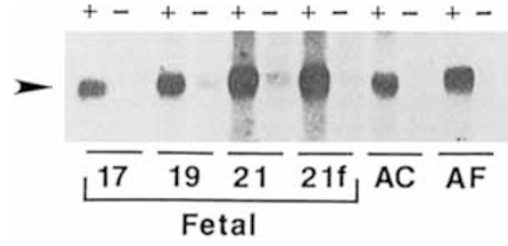

Fig. 7. Autophosphorylation of type I IGF receptor from fetal and adult rat liver. Partially purified receptors were prepared from livers of 17-, 19-, and 21-d fetuses, 21-d fetuses of fasted mothers (21f), a control adult $(A C)$, and a fasted adult $(A F)$. Autophosphorylation of the $\mathrm{M}_{\mathrm{r}}=$ 95000 type I IGF receptor $\alpha$-subunit (arrow) was carried out in the presence $(+)$ or absence $(-)$ of 32 nM IGF-I.

creased ligand-mediated receptor degradation, or a combination of both.

A difficult aspect of the present studies is ascertainment of the IGF receptors and binding proteins that are measured in the competitive binding assays. The change ( $20 \%$ increase) in affinity-labeled type I IGF receptor from d 17 to 21 of gestation was considerably less than the observed increase in binding capacity. Similarly, the degree with which IGF-I binding decreased during the first 2 wk of life was not reflected in a comparable decrease in affinity-labeling. Fetal (19) and adult (20) rat liver membranes contain type II IGF receptors. Our own data demonstrate the presence of IGFBP in hepatic membrane preparations. However, neither type II IGF receptors (20) nor IGFBP (21) are susceptible to inhibition of IGF-I binding by insulin. Because $>80 \%$ of fetal hepatic membrane binding was sensitive to insulin, we conclude that our binding assay mainly measured the type I IGF receptor. The multiple affinity-labeled bands on the more highly exposed autoradiograms (Figs. 4 and 5) probably do not contribute significantly to binding, inasmuch as they were present in samples that had little IGF-I-specific binding.

Similar to the findings of Caro et al. (22), who studied both adult human hepatocytes and adult rat liver, we detected little IGF-I-specific binding in adult rat liver. However, type I IGF receptors were readily detected by affinity-labeling. This is con- sistent with the findings of Venkatesan and Davidson (23), who were able to demonstrate the presence of type I IGF receptors in adult rat liver using competitive binding and affinity-labeling. In addition, we found that IGF-I stimulated phosphorylation of a $\mathbf{M}_{\mathrm{r}}=95000$ protein purified by wheat germ lectin chromatography. Identity of this protein with the $\beta$-subunit of the type I IGF receptor is supported by the dose-response curve shown in Figure 6. Phosphorylation was stimulated at a concentration of IGF-I $(32 \mathrm{nM})$ too low to activate the insulin receptor kinase. Thus, it appears that adult liver membranes contain functional type I IGF receptors.

Fasting of adult rats resulted in a 2.5 -fold increase in affinitylabeled type I receptor. This result complements those of Lowe et al. (24), who also studied the effects of $48 \mathrm{~h}$ of fasting in the adult rat on IGF-I binding. These authors did not investigate changes in hepatic binding because basal levels were low. However, our affinity-labeling results indicate an increase comparable to that seen in the heart (24), another organ with relatively low basal binding. It appears that the regulation of type I IGF receptors in liver parallels that in other tissues. This may be a consequence of decreased receptor turnover coincident with diminished hepatic IGF-I synthesis during fasting $(12,24)$. These results, taken together with the autophosphorylation studies, are consistent with an autocrine/paracrine action of the IGF in adult liver. This interpretation is supported by the finding that adult rat hepatocytes in culture are stimulated to proliferate by IGF-I at concentrations most consistent with action via the type I receptor (25).

In contrast to the effects of fasting in the adult rat, limitation of nutrients to the fetal rat via maternal fasting does not lead to a change in IGF-I binding or affinity-labeling. This differs from regulation of the hepatic insulin receptor, which we have shown increases in growth-retarded fetuses of fasted mothers (14). Fetal rat liver ${ }^{125} \mathrm{I}$-insulin-specific binding and maximum insulin binding calculated from Scatchard analyses correlated inversely with a wide range of diminishing insulin concentrations, consistent with decreased insulin-dependent receptor turnover. Extended interpretation of the present study will require investigation into the effects of fetal nutritional perturbation on fetal hepatic IGF- 
I secretion. In addition, regulation of receptor kinase $\mathrm{sp}$ act represents another mechanism for modulation of IGF effect and is a subject for further investigations.

Acknowledgments. The authors thank Dr. Ian Ocrant for performance of the Western ligand blot analysis.

\section{REFERENCES}

1. Rechler MM, Nissley SP 1985 The nature and regulation of the receptors for insulin-like growth factors. Annu Rev Physiol 47:425-442

2. Ullrich A, Gray A, Tam AW, Yang-Feng T, Tsubokawa M Collins C, Henzel W, Le Bon T, Kathuria S, Chen E, Jacobs S, Francke U, Ramachandran J, Fujita-Yamaguchi Y 1986 Insulin-like growth factor I receptor primary structure: comparison with insulin receptor suggests structural determinants that define functional specificity. EMBO J 5:2503-2512

3. Jacobs S, Kull FC, Earp HS, Svoboda M, Van Wyk JJ, Cuatrecasas P 1983 Somatomedin-C stimulates the phosphorylation of the beta-subunit of its own receptor. J Biol Chem 258:9581-9584

4. Rubin JB, Shia MA, Pilch PF 1983 Stimulation of tyrosine-specific phosphorylation in vitro by insulin-like growth factor I. Nature 305:438-440

5. Zick Y, Sasaki N, Rees-Jones RW, Grunberger G, Nissley SP, Rechler MM 1984 Insulin-like growth factor-I (IGF-I) stimulates tyrosine kinase activity in purified receptors from a rat liver cell line. Biochem Biophys Res Commun 119:6-13

6. Morgan DO, Edman JC, Standring DN, Fried VA, Smith MC, Roth RA, Rutter WJ 1987 Insulin-like growth factor II receptor as a multifunctional binding protein. Nature 329:301-307

7. Lund PK, Moats-Staats BM, Hynes MA, Simmons JG, Jansen M, D'Ercole AJ, Van Wyk JJ 1986 Somatomedin-C/insulin-like growth factor-I and insulin-like growth factor-II mRNAs in rat fetal and adult tissues. $J$ Biol Chem 261:14539-14544

8. Massague J 1983 Epidermal growth factor-like transforming growth factor: II Interaction with epidermal growth factor receptors in human placenta membranes and A431 cells. J Biol Chem 258:13614-13620

9. Fausto N, Mead JE, Gruppuso PA, Braun L 1990 TGF-beta in liver development, regeneration and carcinogenesis. Ann NY Acad Sci 593:231-242

10. Gruppuso PA 1989 Expression of hepatic transforming growth factor receptors during late gestation in the fetal rat. Endocrinology 125:3037-3043
11. Hill DJ, Strain AJ, Milner RDG 1986 Presence of transforming growth factorbeta-like activity in multiple fetal rat tissues. Cell Biol Int Rep 10:915-922

12. Van Wyk JJ, Underwood LE 1978 The somatomedins and their actions. In: Litwack G (ed) Biochemical Actions of Hormones, Vol 5. Academic Press, New York, pp 101-148

13. Gruppuso PA, Brautigan DL 1989 Induction of hepatic glycogenesis in the fetal rat. Am J Physiol 256:E49-E54

14. Gruppuso PA 1989 Effects of fetal hypoinsulinemia on fetal hepatic insulin binding in the rat. Biochim Biophys Acta 1010:270-273

15. Scatchard G 1949 The attractions of proteins for small molecules and ions. Ann NY Acad Sci 51:660-672

16. Ocrant I, Pham H, Oh Y, Rosenfeld RG 1989 Characterization of insulin-like growth factor binding proteins of cultured rat astroglial and neuronal cells. Biochem Biophys Res Commun 159:1316-1322

17. Gruppuso PA, Boylan JM, Posner BI, Faure R, Brautigan DL 1990 Hepatic protein phosphotyrosine phosphatase: dephosphorylation of insulin and epidermal growth factor receptors in normal and alloxan diabetic rats. J Clin Invest $85: 1754-1760$

18. Werner $H$, Woloschak $M$, Adamo $M$, Shen-Orr Z, Roberts CT, LeRoith D 1989 Developmental regulation of the rat insulin-like growth factor I receptor gene. Proc Natl Acad Sci USA 86:7451-7455

19. Senior PV, Byrne S, Brammar WJ, Beck F 1990 Expression of the IGF-II/ mannose-6-phosphate receptor mRNA and protein in the developing rat. Development 109:67-73

20. Massague J, Czech MP 1982 The subunit structures of two distinct receptors for insulin-like growth factors I and II and their relationship to the insulin receptor. J Biol Chem 257:5038-5045

21. Hintz RL 1984 Plasma forms of somatomedin and the binding protein phenomenon. Clin Endocrinol Metab 13:31-42

22. Caro JF Poulos J, Ittoop O, Pories WJ, Flickinger EG, Sinha MK 1988 Insulin like growth factor I binding in hepatocytes from human liver, human hepatoma, and normal, regenerating, and fetal rat liver. J Clin Invest 81:976981

23. Venkatesan N, Davidson MB 1990 Insulin-like growth factor I receptors in adult rat liver: characterization and in vivo regulation. Am J Physiol 258:E329-E337

24. Lowe WL, Adamo M, Werner H, Roberts CT, LeRoith D 1989 Regulation by fasting of rat insulin-like growth factor $I$ and its receptor: effects on gene expression and binding. J Clin Invest 84:619-626

25. Koch KS, Shapiro $P$, Shelly $H$, Leffert HL 1982 Rat hepatocytes proliferation is stimulated by insulin-like peptides in defined medium. Biochem Biophys Res Commun 109:1054-1057 